\title{
Purification and Serology of a Japanese Isolate of Barley Yellow Dwarf Virus
}

\author{
Akira Matsubara*, Makoto Kojima**, Shinji Kawano*, Masaaki Narita**, \\ Manami Hattori**, Ichiro UyedA* and Eishiro ShiKata*
}

\begin{abstract}
A Japanese isolate of barley yellow dwarf virus (BYDV) was purified from infected plants by an improved procedure. The procedure included extraction of the virus by grinding the frozen plant tissues in a meat grinder followed by regrinding in phosphate buffer with motar and pestle for extended periods (more than $2 \mathrm{hr}$ ) in room temperature, clarification of the sap with chloroform, concentration of the virus by polyethylene glycol, two cycles of differential centrifugation and a sucrose density gradient centrifugation. The average yield of the virus was $44 \mu \mathrm{g}$ per $100 \mathrm{~g}$ tissues. The Japanese isolate had particle diameter of $27.3 \mathrm{~nm}$ (2\% PTA, pH 5.0) and UV absorbance spectrum with an average A260/ A280 ratio of 1.71. In ELISA using the double antibody sandwich method, the virus reacted only with homologous antiserum but not with antiserum to potato leafroll virus (PLRV), and vice versa. The virus, however, reacted slightly with heterologous antisera to other luteoviruses such as PLRV, soybean dwarf and beet western yellows viruses in agar gel double diffusion tests.
\end{abstract}

(Received October 20, 1984)

Key Words : BYDV, purification, serology.

\section{Introduction}

Several vector-specific and non-specific variants of barley yellow dwarf virus (BYDV) have been reported in Canada ${ }^{4,12)}$, and the United States ${ }^{13,16)}$, but no variants of the virus have been confirmed in Japan. In 1983, Kojima et al. reported the occurrence of BYDV on barley plants in Japan ${ }^{8)}$. A Japanese isolate of the virus, BYDV 805, is transmitted selectively by the aphid Rhopalosiphum padis) and causes specific cytopathic changes within phloem cells of barley plants similar to viruses in Gill and Chong's subgroup $2^{4,9)}$. Based on its vector specificity and cytopathology, we have concluded that isolate 805 is identical with the $R$. padi-specific variant of $\mathrm{BYDV}^{8,9}$.

Further investigation of the properties of the virus have been hampered by difficulties in purification, low yield and lack of a simple and convenient assay method ${ }^{1}$. Recently, however, improved methods of purification and serological assay have been developed for several luteoviruses ${ }^{2,5,17}$. We report here on the purification and some properties of BYDV 805 .

\footnotetext{
* Faculty of Agriculture, Hokkaido University, Sapporo 060, Japan

** Faculty of Agriculture, Niigata University, Niigata 950-21, Japan
} 


\section{Materials and Methods}

Virus. The virus (BYDV 805) used was originally isolated from infected barley plants

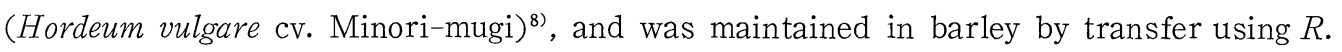
padi. The plants infested with viruliferous aphids were maintained at $20 \mathrm{C}$ with a 16 hr photoperiod for 2 days, then sprayed with insecticide, and kept in the greenhouse at $22 \mathrm{C}$ for about 30 days.

Plants and aphids. Stock colonies of virus-free $R$. padi were maintained on the caged barley plants in a room at $22 \mathrm{C}$. Infected barley and, in some experiments, oat plants were used for purification.

Purification procedure. Entire shoots of infected barley or oat plants were harvested, chopped into pieces about $3 \mathrm{~cm}$ long, and frozen at $-45 \mathrm{C}$ before use. Frozen tissues were ground in a meat grinder and then reground and thoroughly homogenized with sand with a mortar and pestle for a further two hours at room temperature in $2 \mathrm{ml} / \mathrm{g}$ $0.1 \mathrm{M}$ phosphate buffer, $\mathrm{pH}$ 7.0. The homogenate was squeezed through double layers of cheesecloth and the filtrate was clarified by adding $1 / 3$ vol. of chloroform, and blending for $3 \mathrm{~min}$. After centrifugation at $3,000 \mathrm{rpm}$ for $15 \mathrm{~min}$, the aqueous phase was adjusted to $8 \%(\mathrm{w} / \mathrm{v}$ ) with polyethylene glycol (PEG 6,000) and $0.2 \mathrm{M}$ with $\mathrm{NaCl}$, and then stirred at room temperature for $60 \mathrm{~min}$. The mixture was centrifuged at $5,000 \mathrm{rpm}$ for $15 \mathrm{~min}$ at $4 \mathrm{C}$, and the pellets were resuspended in $0.1 \mathrm{M}$ phosphate buffer containing 1\% Triton $\mathrm{X}-100$. The suspension was then clarified by centrifugation for $15 \mathrm{~min}$ at $10,000 \mathrm{rpm}$ in a Hitachi RP30 rotor at room temperature. The supernatant was layered over a $20 \%$ sucrose cushion in $0.1 \mathrm{M}$ phosphate buffer, $\mathrm{pH} 7.0$ (7 ml/tube) and centrifuged at $27,000 \mathrm{rpm}$ for $180 \mathrm{~min}$ in a RP30 rotor. The pellets were drained and resuspended in a small amount of $0.1 \mathrm{M}$ phosphate buffer, $\mathrm{pH} 7.0$ at $4 \mathrm{C}$. After centrifugation for $15 \mathrm{~min}$ at $10,000 \mathrm{rpm}$ in a Hitachi RP40 rotor at room temperature, the supernatants were given one cycle of differential centrifugation. Two $\mathrm{ml}$ of the resultant viral suspensions were layered on sucrose density gradients (10-40\% sucrose), and centrifuged in a Hitachi RPS25 rotor for $180 \mathrm{~min}$ at $22,500 \mathrm{rpm}$ at $4 \mathrm{C}$. The gradients were scanned with an ISCO UA-2 ultraviolet analyser on the sensitive scale $(\mathrm{A} 254=0.5)$, and fractionated with an ISCO fractionator. The virus zones were collected, diluted with $0.1 \mathrm{M}$ phosphate buffer, and pelleted by centrifugation for $90 \mathrm{~min}$ at $36,000 \mathrm{rpm}$ in a RP40 rotor. The final pellets were suspended in $1 \mathrm{ml}$ of $0.1 \mathrm{M}$ phosphate buffer, $\mathrm{pH} 7.0$ and stored at $-90 \mathrm{C}$ until use.

Serological tests. Antisera to BYDV 805 were made by giving one intramuscular and four intravenous injections of purified preparations (c. $20 \mu \mathrm{g} /$ injection) to two rabbits. Titrations of the antisera were made by the ring interface test. For ELISA, gamma globulin and conjugate were prepared by the modified method described previously $^{7)}$. Crude preparations as antigens were obtained by grinding infected plants in PBS-Tween ${ }^{7)}$. Ouchterlony double diffusion tests were made in $0.85 \%$ special AgarNoble (Difco Lab) in neutral phosphate-buffered saline containing $0.02 \%$ sodium azide. The well pattern consisted of a central well (4 mm in diameter) located $6 \mathrm{~mm}$ from 
each of six peripheral wells $(2.5 \mathrm{~mm}$ in diameter). After addition of the reactants, the plates were incubated in a moist chamber at $37 \mathrm{C}$ for at least 3 days. We used antisera to beet western yellows (BWYV), potato leafroll (PLRV), soybean dwarf (SDV) and tobacco necrotic dwarf (TNDV) viruses. Antisera to SDV and TNDV were kindly supplied by T. Tamada, Hokkaido Agricultural Experiment Station, and S. Kubo, Central Research Institute, The Japan Tobacco and Salt Public Corporation, respéctively. Antisera to PLRV and BWYV were from the Hokkaido University Collection.

Bioassay and electron microscopy. Purified preparations were assayed for infectivity by the membrane feeding method ${ }^{8)}$. Electron micrographs were taken of preparations negatively stained in $2 \%$ PTA or $2 \%$ uranyl acetate. Grids were examined in a JEM 100B electron microscope at $80 \mathrm{KV}$.

\section{Results}

\section{Purification}

Complete homogenization of plant materials for extended periods over 2 hours at room temperature was found in preliminary experiments to give more effective virus extraction than similar treatment in the cold room. A visible band was formed at 27$29 \mathrm{~mm}$ from the meniscus of the sucrose density gradient column after centrifugation. Figure 1 shows a scan of a centrifuged gradient column on which a partially purified preparation from $200 \mathrm{~g}$ infected barley plants had been layered. The peak in Fig. 1 corresponds to the band visible in the column. The band contained many small isometric particles (Plate I) and proved to be infectious. To check efficiency of virus extraction, the residue containing fibrous materials after sqeezing was re-extracted in 0.1 $\mathrm{M}$ citrate buffer, $\mathrm{pH} 6.0$ containing $1 \%$ Driselase (w/v), shaken for 2 hours at $28 \mathrm{C}$, and followed by the same purification procedure. No detectable virus was extracted from the fibrous residue. The average yield of BYDV 805 was $44 \mu \mathrm{g}$ per $100 \mathrm{~g}$ of tissue, assuming an $\mathrm{A} 260$ of 8.6 for a $1 \mathrm{mg} / \mathrm{ml}$ concentration ${ }^{17)}$. Virus yields from oats and barley plants were almost the same, and were generally higher from plants grown in winter than those grown in summer, even under temperature controlled conditions.

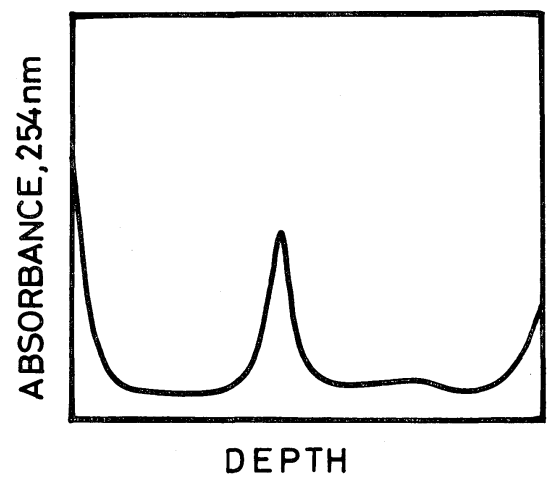

Fig. 1. Scan of sucrose density gradient tube after addition of $2 \mathrm{ml}$ of a partially purified preparation of a Japanese isolate of barley yellow dwarf virus, and centrifugation for $180 \mathrm{~min}$ at $22,500 \mathrm{rpm}$ in a RPS25 rotor at $4 \mathrm{C}$. 


\section{Ultraviolet absorbance spectrum}

The spectrum obtained from the purified BYDV 805 was characteristic of a nucleoprotein, having a maximum at $260 \mathrm{~nm}$ and a minimum at $240 \mathrm{~nm}$. The A260/280 ratio for BYDV 805 was 1.71 , suggesting a RNA content of about $26 \%$.

\section{Electron microscopy}

Electron micrographs of purified preparations of BYDV 805 are shown in Plate I (A-D). The virus particles were isometric in shape but their size was variable depending on negative staining conditions, i. e., about $27.3 \mathrm{~nm}(26-28 \mathrm{~nm}, 87 \%)$ in $2 \%$ PTA at $\mathrm{pH} 5.0$, and about $28 \mathrm{~nm}(27-29 \mathrm{~nm}, 90 \%)$ in $2 \%$ PTA at pH 6.0 and about $30 \mathrm{~nm}$ (29$31 \mathrm{~nm}, 92 \%)$ in $2 \%$ uranyl acetate at $\mathrm{pH} 4.3$, respectively. The virus particles were almost disrupted when stained in $2 \%$ PTA at $\mathrm{pH} 7.0$ (Plate I-C).

\section{ELISA}

Titres of antisera obtained from two rabbits (57-5 and $57-4)$ were $1 / 1024$ and $1 /$ 512, respectively. Further investigations were conducted with antiserum (57-5) having a titre of $1 / 1024$. The optimum ELISA reaction was obtained when $\gamma$-globulin for coating the plate was used at concentration of $10 \mu \mathrm{g} / \mathrm{ml}$ and $100-$ fold diluted conjugate was used. Viral antigen was easily detected by ELISA in crude sap of infected plants but no viral antigen was detected from single viruliferous aphid under the same conditions.

The serological relationship between BYDV 805 and PLRV was examined by ELISA. As shown in Fig. 2, each virus antigen only reacted with $\gamma$-globulin from the homologous

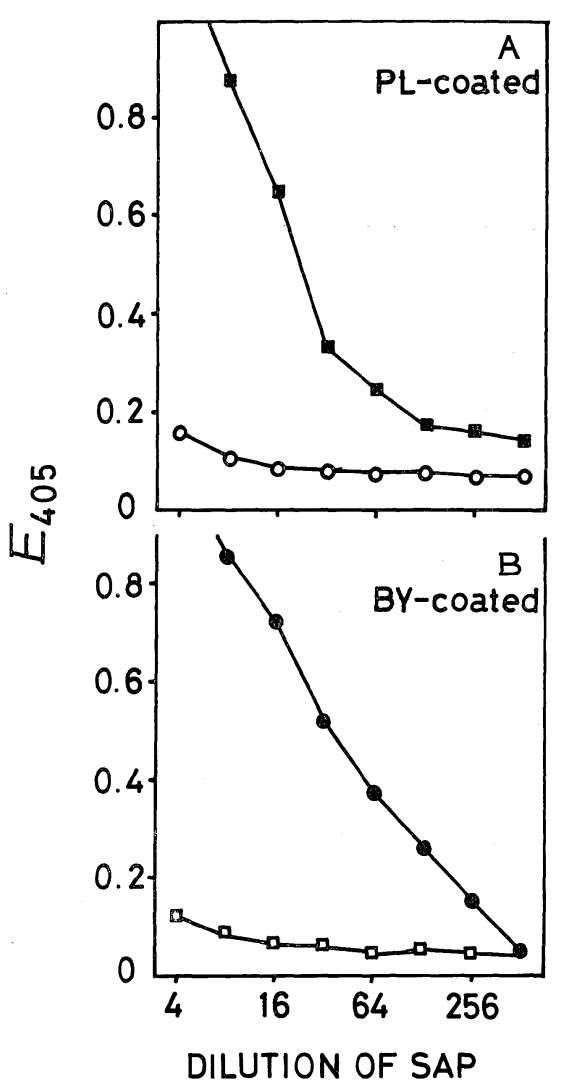

antiserum.

\section{Agar gel double diffusion tests}

In tests with purified preparations (c. $50 \mu \mathrm{g} /$ $\mathrm{ml}$ ) of BYDV 805 , the homologous antiserum reacted at dilutions up to $1 / 128$, and the heterologous antisera to SDV, PLRV and BWYV at dilutions up to $1 / 8,1 / 4$ and $1 / 2$, respectively (Table 1). No reaction was obtained with undiluted antiserum to TNDV. When BYDV 805 antiserum at dilution of $1 / 8$ and heterologous antisera to SDV, PLRV and BWYV at dilution of $1 / 2$ were alternately placed in peripheral wells against a purified preparation of BYDV in the central well, a coalescing precipitin line was obtained. These tests provide evidence

Fig. 2. ELISA values obtained in homologous and heterologous titrations of crude preparations of: A, PLRV (- and BYDV (O-O) against anti-PLRV Ig and B, PLRV ( $\square-\square$ ) and BYDV (-) against anti-BYDV Ig. Plate A and B were coated with anti-PLRV Ig and anti-BYDV Ig, respectively, at a concentration of $10 \mu \mathrm{g} / \mathrm{ml}$. ELISA values were obtained with enzyme conjugates diluted to $1: 400$ (A, PLRV) and 1:100 (B, BYDV). 
Table 1. Reactions of barley yellow dwarf virus with luteovirus antisera assessed by agar gel double diffusion tests

\begin{tabular}{c|c|c}
\hline \hline Antisera to & Homologous titre & Titre to BYDV \\
\hline BYDV & $1 / 1024^{\mathrm{a}}$ & $1 / 128$ \\
BWYV & $1 / 512^{\mathrm{a}}$ & $1 / 2$ \\
PLRV & $1 / 2048^{7)}$ & $1 / 4$ \\
SDV & $1 / 2048^{6}$ & $1 / 8$ \\
TNDV & $1 / 4096^{10}$ & - \\
\hline
\end{tabular}

a) ring interface test (see Materials and Methods).

that these four viruses are distantly serologically related.

\section{Discussion}

It has been shown that extraction procedure is most important for increasing virus yield from plants infected with BYDV ${ }^{16)}$. In a previous paper, we described how infectious BYDV could be prepared by treating fibrous materials with the enzyme, Driselase ${ }^{8)}$. The present experiments showed that complete homogenization of plant tissues for more than 2 hours at room temperature was more effective than Driselase treatment because no detectable virus was recovered after enzyme treatment from the residues containing fibrous materials obtained from the first extraction. Hammond et al. ${ }^{5)}$ also succeeded in recovering sufficient amounts of the Indiana isolate of BYDV from plants which were blended at 15 -min intervals for 2.5 hours without enzyme. Paliwal ${ }^{12)}$ succeeded in purifying a Canadian isolate of BYDV from freeze-dried tissue, but we obtained rather less yields from liquid nitrogen-treated materials (less than $10 \mu \mathrm{g}$ from $300 \mathrm{~g}$ plant tissue). As Rochow et $a l .{ }^{16)}$ pointed out, virus yields were generally higher from plants grown in the greenhouse during winter than from those grown during summer.

The UV absorbance spectrum of purified preparation of BYDV 805 was quite similar to that obtained by Paliwal with his $R$. padi specific isolate in Canada ${ }^{12)}$.

The virus particles of BYDV 805 were damaged when negatively stained in neutral PTA, as shown in Plate I-C. Rochow and Israe1 ${ }^{15)}$ also reported that virions of the RPV ( $R$. padi specific) isolate of BYDV stained with PTA at pH 6.85 were disrupted, but those of the MAV (Macrosiphum avenae specific) isolate were not. This suggests that the Japanese isolate is similar to the RPV isolate in the United States.

Since Lister and Rochow ${ }^{11)}$ reported the usefulness of ELISA for detecting BYDV in crude extracts, many such studies have been reported ${ }^{3,5,14)}$. Using the Japanese isolate of BYDV, we also confirmed that ELISA is effective in detecting BYDV in crude sap. The availability of an antiserum to BYDV 805 and the sensitivity of ELISA will now make routine diagnosis of BYDV possible also in Japan.

No serological comparison by ELISA between BYDV and PLRV has yet been reported. In our experiments using the double antibody sandwich method, positive reactions occurred only in each homologous test. This fact shows that the double antibody sandwich method of ELISA is extremely virus (strain) specific. In agar gel double dif- 
fusion tests, however, purified preparations of BYDV 805 reacted distantly with heterlogous antisera to other luteoviruses such as PLRV, SDV and BWYV, suggesting that these four viruses are distantly serologically related.

We thank Drs. S. Kubo, Central Research Institute, The Japan Tobacco and Salt Public Corporation, and T. Tamada, Hokkaido Central Agricultural Experiment Station, for their generosity in supplying antisera to TNDV and SDV, respectively. We are also indebted to Dr. R. G. Milne, Instituto di Fitovirologia Applicata, Italy, for his critical reading of this manuscript.

\section{Literature cited}

1. Brakke, M. K. and Rochow, W. F. (1974). Virology $61: 240-248$.

2. D’Arcy, C. J., Hewing, A. D., Burnett, P. A. and Jedlinski, H. (1983). Phytopaphology $73: 755^{-}$ 759.

3. Doupnik, B., Stuckey, R. E., Bryant, G. R. and Pirone, T. P. (1982). Plant Disease $66: 812-815$.

4. Gill, C. C. and Chong, J. (1979). Virology $95: 59-69$.

5. Hammond, J., Lister, R. M. and Foster, J. E. (1983). J. gen. Virol. $64: 667-676$.

6. Kojima, M. and Tamada, T. (1976). Phytopath. Z. $85: 237-250$.

7. Kojima, M., Takizawa, T., Uyeda, I. and Shikata, E. (1982). Ann. Phytopath. Soc. Japan 48 : 458465.

8. Kojima, M., Matsubara, A., Yanase, S. and Toriyama, S. (1983). Ibid 49 : 338-346.

9. Kojima, M. and Yanase, S. (1984). Bull. Fac. Agr. Niigata Univ. 36:11-20.

10. Kubo, S. and Takanami, Y. (1979). J. gen. Virol. 42:387-398.

11. Lister, R. M. and Rochow, M. F. (1979). Phytopathology $69: 649-654$.

12. Paliwal, Y, C. (1978). Phytopath. Z. $92: 240-246$.

13. Rochow, W. F. (1970). CMI/AAB. Descriptions of Plant Viruses No. 32.

14. Rochow, W. F. and Carmichael, L. E. (1979). Virology $95: 415-420$.

15. Rochow, W. F. and Israel, H. W. (1977). In The Atlas of Insect and Plant Viruses (Maramorosch, K. eds.) Academic Press, N. Y. pp. 363-369.

16. Rochow, W. F., Aapola, A. I.E., Brakke, M. K. and Carmichael, L. E. (1971). Virology 46 : 117126.

17. Takanami, Y. and Kubo, S. (1979). J. gen. Virol. $44: 153-159$.

\section{和 文 摘 要}

松原 旭・小島 誠・河野伸二・成田正明・服部まなる・上田一郎・四方英四郎：オオムギ黄萎ウイルスの 精製と血清反応

オオムギより分離したオオムギ黄萎ウイルスの 1 分離株（BYDV 805）を用い，精製方法を検討し，抗血清 の作成を試みた。凍結葉を室温で長時間磨砕するととにより充分にウイルスが抽出された。クロロホルムによ る清澄化の後, ポリエチレングリコールルよる濃縮, 分画 遠心 2 回反復としょ糖濃度勾配遠心により精製し た。ウイルス収量は病葉 $100 \mathrm{~g}$ 当り平均 $44 \mu \mathrm{g}$ であった。リンタングステン酸によるネガティブ染色で精製ウ

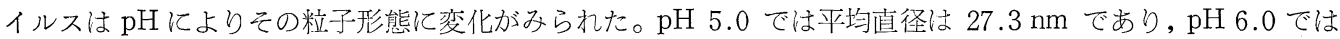

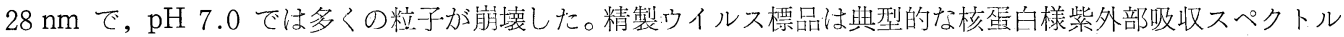
を示し，その A260/A280 比は1.71であった。精製ウイルスを免疫原として 1 回の筋肉注射と 4 回の静脈注射 により力洒1,024倍の抗血清を得ること犬゙できた。本抗血清より分離した $\gamma$-グロブリンを用いた酵素結合抗体 法（直接サンドゥィッチ法）により粗汁液中のゥイルス抗原の検出が可能となった。また，本ウイルスとジャ ガイモ葉巻ウイルス（PLRV）とを用い，同法により比較したところ，それぞれホモロガスな組合せでのみ反 応が認奶ら机た。一方, 寒天ゲル内二重拡散法では本ウイルスと PLRV, ダイズ矮化ウイルス, beet western yellows virus に対する各抗血清との間に微弱ながら陽性の反応が認められた。 


\section{Explanation of plate}

Plate I (A-D)

Electron micrographs of particles of the Japanese isolate of barley yellow dwarf virus after sucrose density-gradient centrifugation. The preparations were mounted in $2 \%$ sodium phosphotungstate at $\mathrm{pH} 5.0(\mathrm{~A}), 6.0(\mathrm{~B}), 7.0(\mathrm{C})$ and $2 \%$ uranyl acetate at $\mathrm{pH} 4.3$, respectively. Note disrupted particles when stained in $2 \%$ PTA at pH 7.0. Magnification: $\times 200,000$

\section{Plate I}
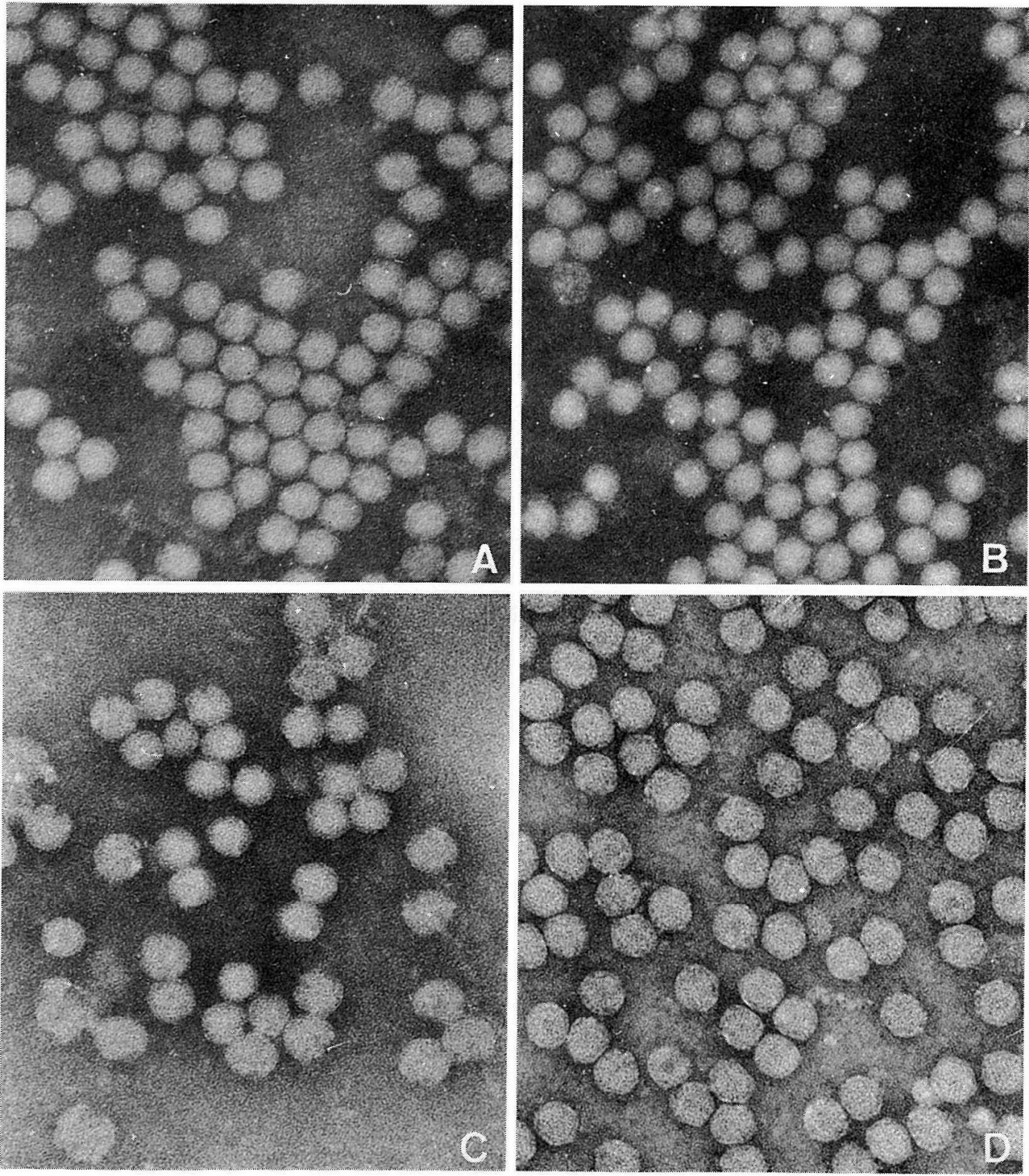